\title{
Effectiveness of Calcium Sulfate Scale Inhibitors in Spent Hydrochloric Acid/Seawater System
}

\author{
He $\mathrm{J}^{*}$, Arensman $\mathrm{D}$ and Nasr-El-Din HE
}

SPE, Texas A\&M University, Texas, USA

\begin{abstract}
Previous results have reported the precipitation of calcium sulfate during matrix acid treatments when seawater was used to prepare $\mathrm{HCl}$-based acid. Precipitations of calcium sulfate causes severe damage on the permeability of carbonate reservoirs and negatively impacts the performance of acid treatments. Typically, scale inhibitors are applied in the field to prevent the formation of calcium sulfate scale, and the object of this study is to evaluate the effectiveness of different types of scale inhibitors to inhibit the formation of calcium sulfate scale during the acid stimulation process. Scale inhibition efficiency was determined in batch tests under different temperatures $\left(77\right.$ to $\left.210^{\circ} \mathrm{F}\right)$ and different degrees of spent acid conditions. Sulfate ions were analyzed in the samples of the batch tests to detect the precipitations of calcium sulfate. Results showed that application of scale inhibitors can successfully mitigate calcium sulfate scale formation up to $210^{\circ} \mathrm{F}$. At higher temperatures, the rate of calcium sulfate precipitation increased and the effectiveness of all types of scale inhibitors decreased greatly. Most of the scale inhibitors were not effective in acidic conditions and some of the scale inhibitors even precipitated out of the solution in the presence of high concentration of calcium ions. Methylene phoshponic acid scale inhibitor was the most effective one under various experimental conditions. The findings in this study provided information for better calcium sulfate scale control under acid stimulation conditions.
\end{abstract}

Keywords: Calcium sulfate; Scale inhibitor; Acid Treatment; Formation Damage; Seawater

\section{Introduction}

The potential of calcium sulfate precipitation is greatly increased when seawater is used for matrix acidizing treatments [1-3]. In those processes, calcium concentration is greatly increased, due to the reaction of the hydrochloric acid with calcite in the carbonate reservoir rocks. High concentrations of calcium ions will combine with high levels of sulfate ions in seawater, and significantly increase the scaling tendency of calcium sulfate. Moreover, the solubility of calcium sulfate drops greatly once the acid is spent [4-6]. Those two factors account for the precipitation of calcium sulfate once it exceeds the critical scaling tendency of calcium sulfate [7-9]. Calcium sulfate will deposit in the stimulated flow channels [10], possibly causing blockage of pore throats and severely impairing the formation permeability [11]. Hence, decrease well injectivity or productivity $[12,13]$. Even worse, the nucleation and precipitation process of calcium sulfate during acidizing treatments may affect the acid reaction with carbonate rocks, and cause a limited acid stimulation effect [3].

\begin{tabular}{|c|c|}
\hline Arabian Gulf at Kuwait & Ion Concentration, $\mathbf{~ g} / \mathbf{l}$ \\
\hline Chloride $\left(\mathrm{Cl}^{-}\right)$ & 23,000 \\
\hline Sodium $\left(\mathrm{Na}^{+}\right)$ & 15,850 \\
\hline Sulfate $\left(\mathrm{SO}_{4}{ }^{2-}\right)$ & 4,000 \\
\hline Magnesium $\left(\mathrm{Mg}^{2+}\right)$ & 1,765 \\
\hline Calcium $\left(\mathrm{Ca}^{2+}\right)$ & 500 \\
\hline Bicarbonate $\left(\mathrm{HCO}_{3}{ }^{-}\right)$ & 142 \\
\hline Total dissolved solids (TDS), mg/l & 45,157 \\
\hline $\mathrm{pH}$ & 7.8 \\
\hline Density ${ }^{*}, \mathrm{~g} / \mathrm{cm}^{3}$ & 1.028 \\
\hline
\end{tabular}

Table 1: Composition of synthetic seawater.
Typically, the application of scale inhibitors has been an economical method used to mitigate calcium sulfate [14-16]. The use of scale inhibitors may act either as chelating agents to form a soluble complex [17-19], or as threshold inhibitors, which block the development of the supercritical nuclei $[20,21]$, or as retarders of the growth of the calcium sulfate crystals [22-24]. By simply adding an acid-soluble and effective scale inhibitor into the acid system, mineral scale formation can be prevented during the process of acid stimulation [25-27]. In addition, combining scale inhibition and acid stimulation into a single package inherently reduces well intervention costs and well downtime, and therefore achieves significant economic benefits [28]. In this study, the effectiveness of various scale inhibitors to prevent the formation of calcium sulfate was evaluated in acid stimulation process, and the specific challenges of calcium sulfate scale control were discussed.

\section{Experimental Studies}

\section{Fluids preparation}

A synthetic seawater solution was prepared according to the composition of seawater in the Arabian Gulf at Kuwait [29], Table 1. The synthetic seawater with a density of $1.028 \mathrm{~g} / \mathrm{cm} 3$ at $77^{\circ} \mathrm{F}$ was

*Corresponding author: Jia $\mathrm{He}, \mathrm{PhD}$ Student of Petroleum Engineering Department, Texas A\&M University, Texas, USA, Tel: 9798452241; Fax: 9798451307; E-mail: jia.he@pe.tamu.edu

Received July 26, 2013; Accepted October 29, 2013; Published November 07 2013

Citation: He J, Arensman D, Nasr-El-Din HE (2013) Effectiveness of Calcium Sulfate Scale Inhibitors in Spent Hydrochloric Acid/Seawater System. J Pet Environ Biotechnol 4: 159. doi:10.4172/2157-7463.1000159

Copyright: (c) $2013 \mathrm{He} \mathrm{J}$, et al. This is an open-access article distributed under the terms of the Creative Commons Attribution License, which permits unrestricted use, distribution, and reproduction in any medium, provided the original author and source are credited. 
Citation: He J, Arensman D, Nasr-El-Din HE (2013) Effectiveness of Calcium Sulfate Scale Inhibitors in Spent Hydrochloric Acid/Seawater System. J Pet Environ Biotechnol 4: 159. doi:10.4172/2157-7463.1000159

Page 2 of 6

\begin{tabular}{|c|l|c|}
\hline $\begin{array}{c}\text { Abbreviated } \\
\text { Name }\end{array}$ & \multicolumn{1}{|c|}{ Active Ingredient } & $\begin{array}{c}\text { Approxiamate } \\
\text { Activity, \% }\end{array}$ \\
\hline A & Phosphinopolycarboxylic acid & 29 \\
\hline B & Sulfonated polymer & 31 \\
\hline C & Polyacrylic acid & 19 \\
\hline D & P tagged sulfonated polymer & 45 \\
\hline E & $\begin{array}{l}\text { Diethylenetriamine penta(methylene phosphonic } \\
\text { acid) }\end{array}$ & 18 \\
\hline F & $\begin{array}{l}\text { Bis-hexamethylene triamine-penta(methylene } \\
\text { phosphonic) acid }\end{array}$ & 12 \\
\hline
\end{tabular}

Table 2: Scale inhibitors used in this study.

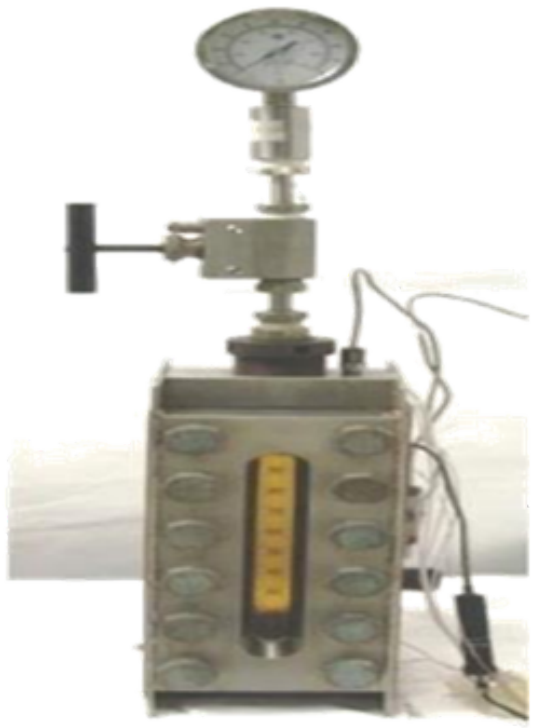

Figure 1: Visual cell.

\begin{tabular}{|c|c|c|c|c|c|}
\hline $\begin{array}{l}\text { Degree of Spent } \\
\text { Acid }\end{array}$ & Case & $\begin{array}{l}\text { Density, } \\
\text { mg/l }\end{array}$ & $\mathrm{pH}$ & $\begin{array}{c}\mathrm{HCl} \\
\underset{w t}{\text { Concentration, }}\end{array}$ & $\begin{array}{c}\text { Sulfate } \\
\text { Concentration, } \\
\text { mg/l }\end{array}$ \\
\hline \multirow{2}{*}{15 wt $\%$ Live $\mathrm{HCl}$} & Acid & 1.07 & 0 & 15.42 & 2300 \\
\hline & Mixtures & 1.04 & 0 & 3.86 & 3510 \\
\hline \multirow{2}{*}{$\begin{array}{l}10 \text { wt } \% \text { Partially } \\
\text { Spent } \mathrm{HCl}\end{array}$} & Acid & 1.1 & 0 & 9.58 & 2820 \\
\hline & Mixtures & 1.05 & 0.08 & 2.65 & 3600 \\
\hline \multirow{2}{*}{$\begin{array}{c}5 \text { wt } \% \text { Partially } \\
\text { Spent } \mathrm{HCl}\end{array}$} & Acid & 1.17 & 0 & 5.03 & 3350 \\
\hline & Mixtures & 1.06 & 0.4 & 1.37 & 3810 \\
\hline \multirow{2}{*}{$\begin{array}{l}1 \text { wt\% Partially } \\
\text { Spent } \mathrm{HCl}\end{array}$} & Acid & 1.18 & 0.5 & 1.11 & 3600 \\
\hline & Mixtures & 1.07 & 1.1 & 0.28 & 3850 \\
\hline \multirow{2}{*}{$\begin{array}{l}0 \text { wt } \% \text { Completely } \\
\text { Spent } \mathrm{HCl}\end{array}$} & Acid & 1.2 & 7.7 & 0 & 3920 \\
\hline & Mixtures & 1.19 & 7.8 & 0 & 3940 \\
\hline
\end{tabular}

Table 3: Properties of spent acids and mixtures of acid with seawater.

used to prepare $\mathrm{HCl}$ acid. All the salts used to prepare the seawater were obtained from Mallinckrodt Chemical Inc. Hydrochloric acid at $15 \mathrm{wt} \%$ was prepared using seawater through dilution of $36 \mathrm{wt} \% \mathrm{HCl}$, which was obtained from Mallinckrodt Chemical Inc., and 0.45 vol\% corrosion inhibitor was added to the acid. The corrosion inhibitor was received from a local service company. To prepare spent-acid solutions, the required amount of calcium chloride was added to prepare spentacid solutions of $10,5,1$, and $0 \mathrm{wt} \% \mathrm{HCl}$ from live $15 \mathrm{wt} \% \mathrm{HCl}$.

\section{Types of scale inhibitors}

Six different types of scale inhibitors were tested for performance comparison. All the scale inhibitors were received from a local service company and the chemistry of all the scale inhibitors were shown in Table 2.

\section{Visual cell}

A Hassler-type visual cell was used to observe the precipitation of calcium sulfate at different temperatures shown in Figure 1. The cell is manufactured by Temco, Inc., and can withstand up to 1000 psi and $300^{\circ} \mathrm{F}$.

\section{Experimental procedures}

In general, the objective of this study is to investigate the effectiveness of scale inhibitors to prevent the formation of calcium sulfate scale during core flood experimental conditions. In our previous work, 10 $\mathrm{cm}^{3}$ of $15 \mathrm{wt} \% \mathrm{HCl}$ was injected into a limestone core with around 30 $\mathrm{cm}^{3}$ of pore volume [3]. Therefore, the experimental procedures used to determine the efficiency of scale inhibitors are as follows:

- $15,10,5,1$, and $0 \mathrm{wt} \% \mathrm{HCl}$ acids were first prepared using seawater.

- Then $10 \mathrm{~cm}^{3}$ of acid and $30 \mathrm{~cm}^{3}$ (approximate one pore volume of core sample) of seawater was mixed, and scale inhibitor was added as well, taking sample \#1. This is the mixture of seawater and spent acid without adding $\mathrm{CaCl}_{2}$.

- Then the amount of $\mathrm{CaCl}_{2}$ produced by acid reaction with calcite was added into solution, taking sample \#2. The properties of different degrees of acid and mixtures of acid and seawater are shown in Table 3.

- The solution was put into the visual cell to be heated up to 150 , 210 , and $250^{\circ} \mathrm{F}$ and samples \#3, \#4, and \#5 were taken.

- A spectrophotometer (Orbeco SP600) was used to measure $\mathrm{SO}_{4}^{2-}$ concentration, using the turbidity method (precipitation with barium chloride).

\section{Results and Discussion}

\section{Precipitation of calcium sulfate without scale inhibitors}

In the first set of batch tests, $10 \mathrm{~cm}^{3}$ of $0 \mathrm{wt} \%$ completely spent $\mathrm{HCl}$ was mixed with $30 \mathrm{~cm}^{3}$ of seawater. The visual cell was heated up to $250^{\circ} \mathrm{F}$ with a confining pressure of $300 \mathrm{psi}$. The sulfate concentration profiles were shown in Figure 2. Sample \#1 was the mixture of acid and seawater without adding $\mathrm{CaCl}_{2}$. Calcium sulfate began to precipitate out of solution even at $77^{\circ} \mathrm{F}$ (sample \#2) and sulfate concentration dropped sharply to $1,300 \mathrm{mg} / \mathrm{l}$ at $210^{\circ} \mathrm{F}$. However, sulfate concentration changed only a little from 210 to $250^{\circ} \mathrm{F}$, possibly to due to the less change in

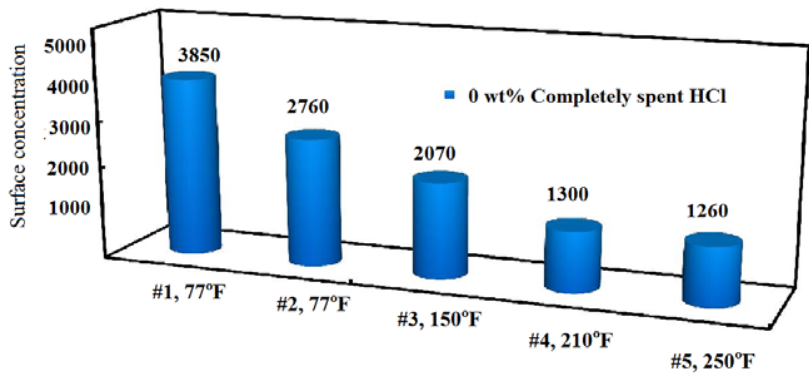

Figure 2: Sulfate concentrations in the acid and seawater mixtures at different temperatures without scale inhibitors. 
Citation: He J, Arensman D, Nasr-El-Din HE (2013) Effectiveness of Calcium Sulfate Scale Inhibitors in Spent Hydrochloric Acid/Seawater System. J Pet Environ Biotechnol 4: 159. doi:10.4172/2157-7463.1000159

Page 3 of 6

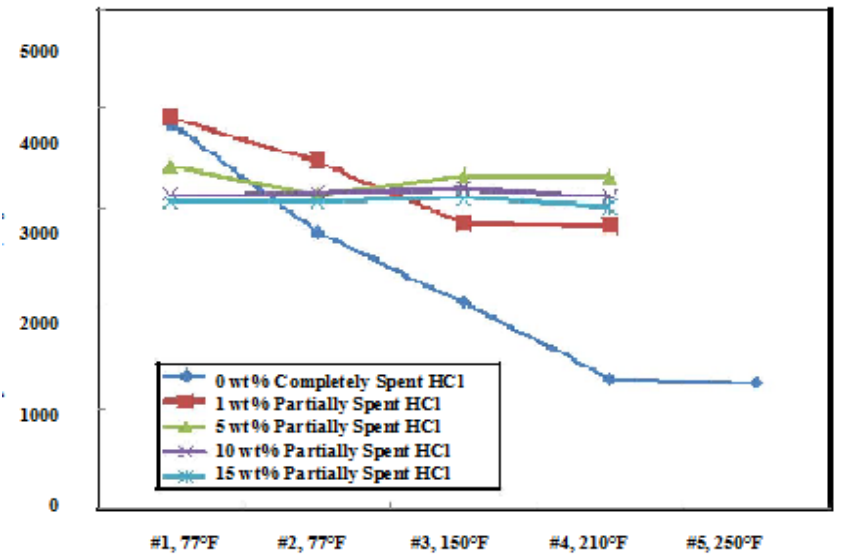

Figure 3: Sulfate concentrations in the acid and seawater mixtures at different temperatures without scale inhibitors.

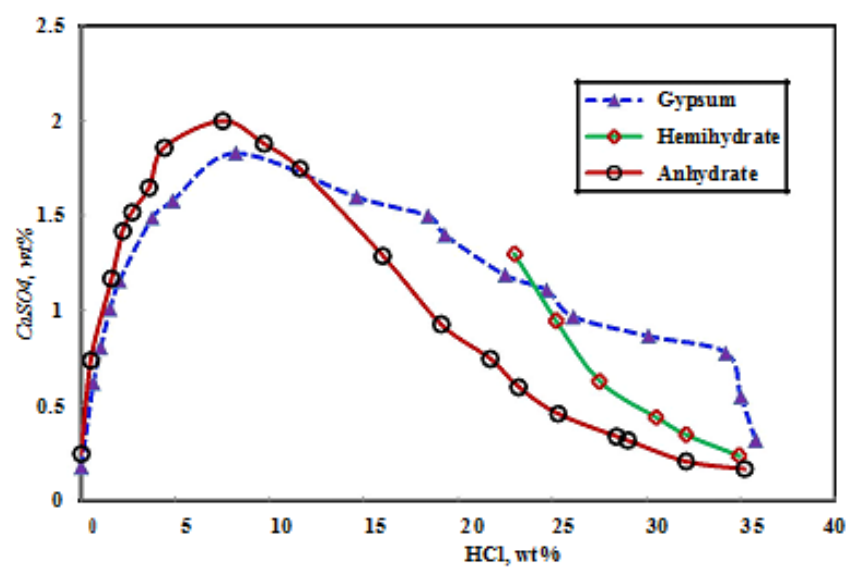

Figure 4: Solubility of calcium sulfate at $77^{\circ} \mathrm{F}$ (Kruchenko and Beremzhanov 1976)

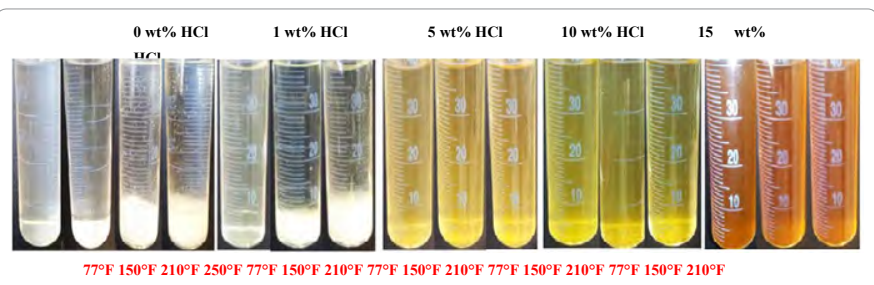

Figure 5: Precipitations were observed in the mixtures of 0 and $1 \mathrm{wt} \%$ spent $\mathrm{HCl}$ and seawater.

solubility of calcium sulfate from 210 to $250^{\circ} \mathrm{F}$. Therefore, the following batch tests were done in the temperatures ranging from 77 to $210^{\circ} \mathrm{F}$.

Figure 3 showed the sulfate concentration profiles under different degrees of acid spent conditions. The sulfate concentrations maintained almost constant in the mixtures of 5,10 , and $15 \mathrm{wt} \%$ acids with seawater. In those cases, the calcium ions produced by the reaction of $\mathrm{HCl}$ with calcite was not high enough to combine with sulfate ions and precipitate calcium sulfate out of solution. Besides, the solubility of calcium sulfate was more than that in completely spent acid, shown in Figure 4 . The more reaction of acid with calcite was, the more calcium ions produced and the less solubility of calcium sulfate was in spent acid. Then calcium sulfate had much scaling tendency to precipitate.
Figure 5 clearly showed the precipitation of calcium sulfate at different temperatures in the mixtures of 0 and $1 \mathrm{wt} \%$ spent acids and seawater. The precipitations were collected at each temperature and were analyzed using Scanning Electron Microscope (SEM). Calcium sulfate was identified and the SEM images were shown in Figure 6. Further batch tests were conducted to test the effectiveness of different scale inhibitors in the mixtures of 0 and $1 \mathrm{wt} \%$ spent acids and seawater.

\section{Performance of scale inhibitor in $0 \mathrm{wt} \%$ completely spent acid}

The effectiveness of different scale inhibitors shown in Table 2 in completely spent acid was tested at different temperatures. Figure 7 showed the sulfate concentration profiles in the presence of $50 \mathrm{ppm}$ different scale inhibitors. $50 \mathrm{ppm}$ scale inhibitor was selected based on the previous results $\mathrm{He}$ et al. [3]. Contrary to the sharp decrease of sulfate concentration with the increment of temperature without adding scale inhibitors, the sulfate levels in the presence of different scale inhibitors kept almost constant at different temperatures, indicating no calcium sulfate precipitation in the solutions. This was also confirmed by the clear solutions at different temperatures shown in Figure 8. Those results showed that all the scale inhibitors performed very well in the mixtures of $0 \mathrm{wt} \%$ completely spent acids and seawater. The $\mathrm{pH}$ value of the mixtures were generally around 7.8 and the calcium ions concentration was the most among all the mixtures of different degree of spent acids and seawater. The main concern for this part is to investigate the effect of $\mathrm{pH}$ value on the effectiveness of scale inhibitors. That is, whether the scale inhibitors would function well in acidic conditions.

\section{Performance of scale inhibitor in $1 \mathrm{wt} \%$ completely spent acid}

Precipitation of calcium sulfate occurred in the mixtures of $1 \mathrm{wt} \%$

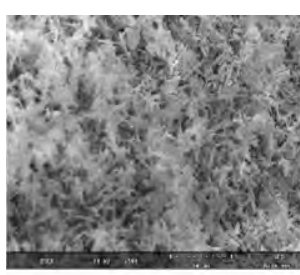

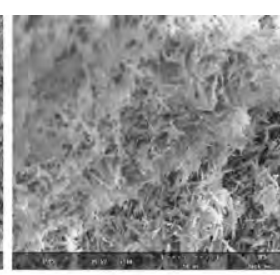

$150^{\circ} \mathrm{F}$

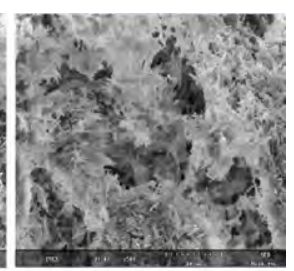

$210^{\circ}$
Figure 6: SEM images of calcium sulfate in the mixtures of completely spent acid and seawater without scale inhibitors.

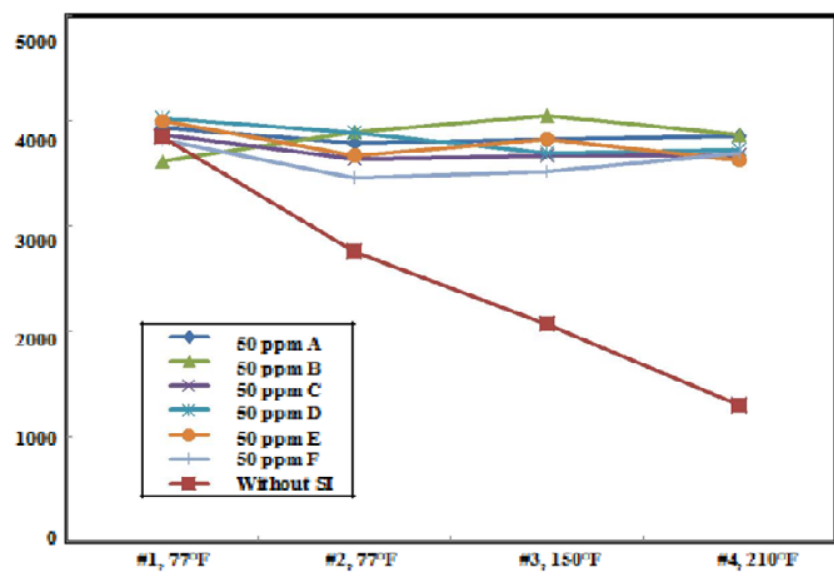

Figure 7: Sulfate concentrations in the mixtures of $0 \mathrm{wt} \%$ completely spent acid and seawater with $50 \mathrm{ppm}$ different scale inhibitors. 


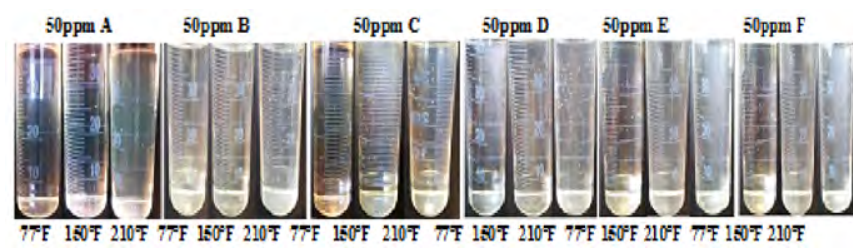

Figure 8: Clear solutions were observed in all the mixtures of $0 \mathrm{wt} \%$ completely spent acid and seawater.

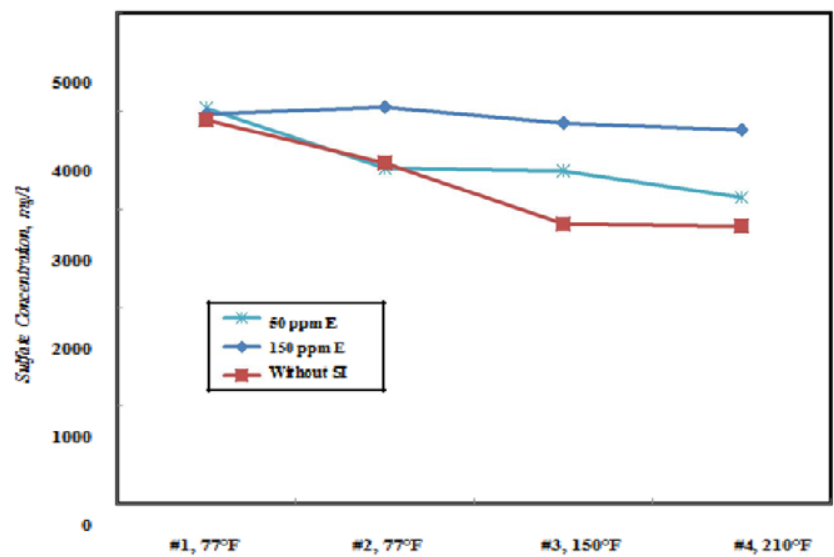

Figure 9: Sulfate concentrations in the mixtures of $1 \mathrm{wt} \%$ spent acid and seawater with $\mathrm{E}$.
50 ppmE

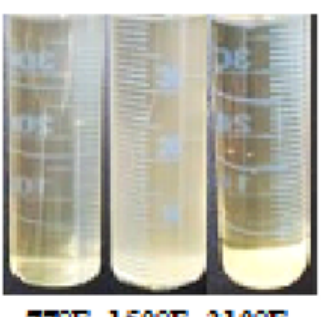

$77^{\circ} \mathrm{F} 150^{\circ} \mathrm{F} 210^{\circ} \mathrm{F}$
150 ppm E

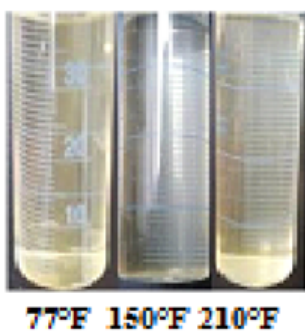

Figure 10: Performance of $E$ as the calcium sulfate inhibitor.

spent acid and seawater, as shown in Figure 5. The $\mathrm{pH}$ value of the mixtures is around 1.1. The performance of all the 6 scale inhibitors can be divided into 3 categories in the very acidic conditions. With the addition of $50 \mathrm{ppm} \mathrm{E}$, less reduction in the sulfate concentration level was observed at high temperatures in Figure 9, but there were still some precipitations of calcium sulfate out of solution (Figure 10). When the concentration of E was increased from 50 to $150 \mathrm{ppm}$, the sulfate level kept almost constant and clear solutions were shown in Figure 10. It was concluded that scale inhibitor $\mathrm{E}$ could function well in acidic conditions. However, higher concentrations of $\mathrm{E}$ were needed even the calcium ions concentration was less than that of mixtures of completely spent acid and seawater.

Figure 11 indicated that $50 \mathrm{ppm} \mathrm{F}$ and $50 \mathrm{ppm} \mathrm{C}$ were not effectively to prevent the precipitation of calcium sulfate out of the solutions at high temperatures $\left(150\right.$ and $\left.210^{\circ} \mathrm{F}\right)$. However, when the concentration of $\mathrm{F}$ was increased from 50 to $150 \mathrm{ppm}$, the sulfate level concentration almost kept constant while there were still some precipitations out of solutions at high temperatures (Figure 12). F is a methylene phosphonic-based scale inhibitor. It could be probably that $\mathrm{F}$ was not compatible with the solution in the presence of high calcium ions concentration and acidic conditions at high temperatures. The performance of $\mathrm{C}$ was different from that of $\mathrm{F}$. When the concentration of $\mathrm{C}$ was increased from 50 to $150 \mathrm{ppm}$, the sulfate concentration dropped sharply, even more that without adding scale inhibitors. Cloudy solution was even observed with the addition of $150 \mathrm{ppm} \mathrm{C}$ at $77^{\circ} \mathrm{F}$. Those findings concluded that some scale inhibitors may function well in neutral conditions, but not certainly function well in acidic conditions. Some scale inhibitors may even be not compatible with the solution at high temperatures while some scale inhibitors may cause more severe damage.

Figure 13 showed the performances of the other 3 scale inhibitors in the mixtures of $1 \mathrm{wt} \%$ spent acid and seawater. B behaved like the performance of $150 \mathrm{ppm}$ F. The sulfate concentration levels kept almost constant but there were precipitation out of solutions shown in Figure 14. When the concentration of B was increased from 50 to $150 \mathrm{ppm}$, more precipitations and more reduction in the sulfate levels were observed at $77^{\circ} \mathrm{F}$. In the presence of high calcium ion concentration and acidic conditions, $\mathrm{B}$ was not compatible with the solutions even at $77^{\circ} \mathrm{F}$. For $\mathrm{A}$ and $\mathrm{D}$, they did not function well in the acidic conditions, confirmed by the reduction in sulfate level and precipitations observed in the tubes. It was interesting to note that more reduction in sulfate level occurred even at $77^{\circ} \mathrm{F}$ when the concentrations of the 3 scale inhibitors were increased from 50 to $150 \mathrm{ppm}$.

Figure 13 and 14 showed that more damage occurred if the concentration of the scale inhibitor was increased even at $77^{\circ} \mathrm{F}$. Further

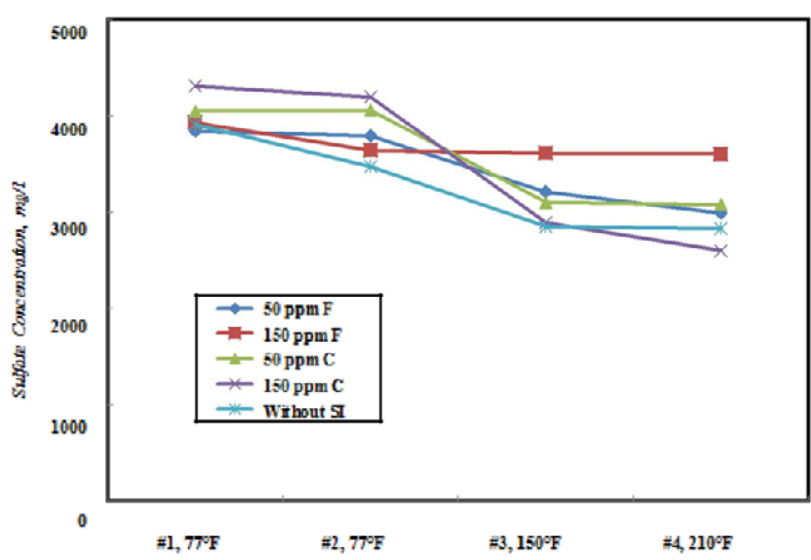

Figure 11: Sulfate concentrations in the mixtures of $1 \mathrm{wt} \%$ spent acid and seawater with $\mathrm{F}$ and $\mathrm{C}$.

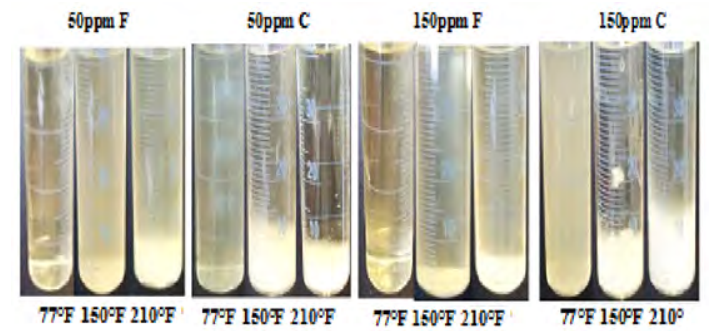

Figure 12: Performance of $F$ and $C$ as the calcium sulfate inhibitors 
Citation: He J, Arensman D, Nasr-El-Din HE (2013) Effectiveness of Calcium Sulfate Scale Inhibitors in Spent Hydrochloric Acid/Seawater System. J Pet Environ Biotechnol 4: 159. doi:10.4172/2157-7463.1000159

Page 5 of 6

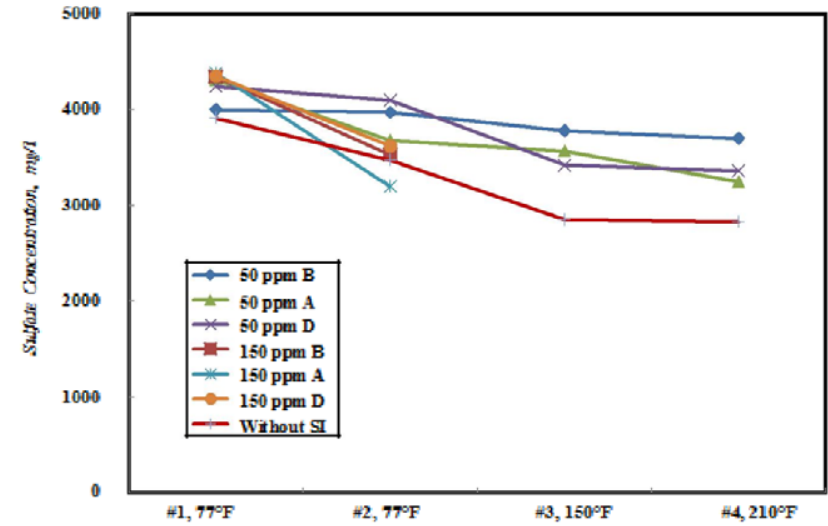

Figure 13: Sulfate concentrations in the mixtures of $1 \mathrm{wt} \%$ spent acid and seawater with $A, B$ and $D$.

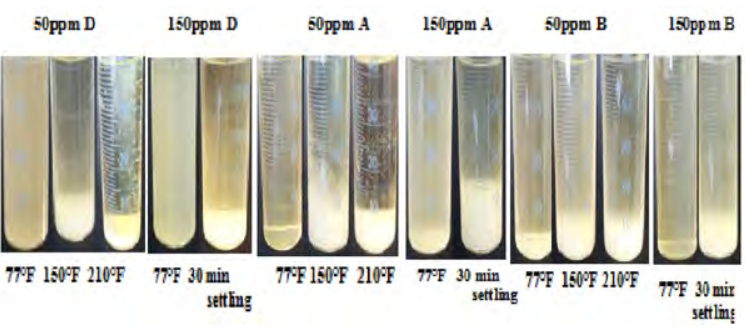

Figure 14: Performance of $A, B$ and $D$ as the calcium sulfate inhibitors.

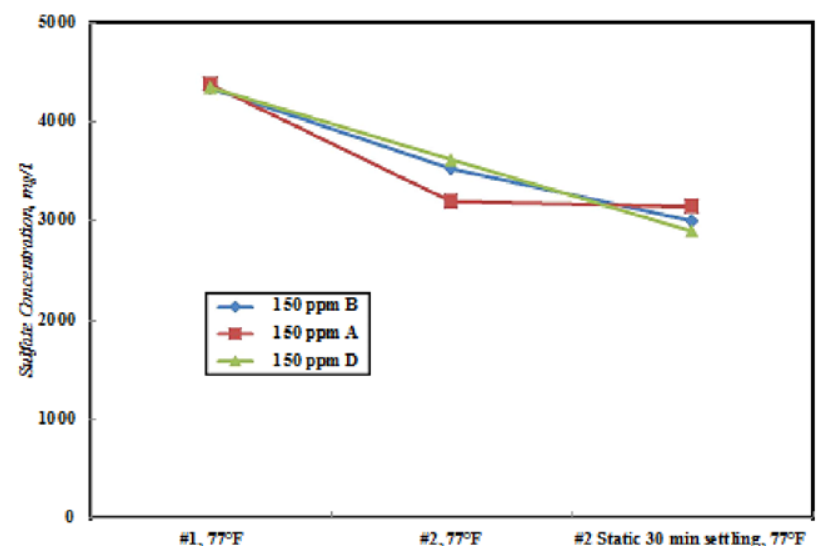

Figure 15: Sulfate concentrations in the mixtures of $1 \mathrm{wt} \%$ spent acid and seawater with $A, B$ and $D$ after 30 min static settling

studies were conducted to investigate settling time effect instead of temperature effect. After statically settling for $30 \mathrm{~min}$, more reduction in sulfate level and more precipitations were observed shown in Figure 15. Those findings concluded that there is one optimum concentration of scale inhibitors used for scale control in acidic conditions. Less scale inhibitor concentration is not enough to prevent formation of scale, but more scale inhibitor usage can cause more damage. All the results of batch tests were summarized in Table 4 and $\mathrm{E}$ was the most effective scale inhibitor under different conditions.

\section{Conclusions}

Based on the batch tests on the effectiveness of 6 different scale inhibitors, the following conclusions can be drawn:

1. In the acid stimulation process, calcium sulfate began to precipitate out of solution when acid was almost completely spent. $50 \mathrm{ppm}$ of different scale inhibitors can successfully prevent the formation of calcium sulfate in the mixtures of completely spent acid and seawater under various temperature conditions.

2. However, most scale inhibitors did not perform well in acidic conditions. Methylene phoshponic acid scale inhibitor (scale inhibitor E) was the only effective one that can prevent the formation of calcium sulfate under various temperature conditions. The other scale inhibitors either were not sufficiently to prevent the formation of calcium sulfate or were not compatible with the solutions in the presence of high calcium ion concentrations and acidic conditions.

3. The findings in this study confirmed that the selections of appropriate scale inhibitors for field use depends on lots of factors, including temperature, $\mathrm{pH}$ value of the solution, and compatibility with solution.

\section{Acknowledgement}

The authors would like to thank members of the Middle East Carbonate Stimulation project for funding this research.

\begin{tabular}{|c|c|c|c|c|c|c|c|}
\hline $\begin{array}{c}\text { Acid } \\
\text { Mixing with } \\
\text { Seawater }\end{array}$ & $\begin{array}{l}\text { Type of } \\
\text { Scale } \\
\text { Inhibitor }\end{array}$ & $\begin{array}{c}\text { Concentration, } \\
\text { ppm }\end{array}$ & $\begin{array}{l}\# 1 \\
77^{\circ} \mathrm{F}\end{array}$ & $\begin{array}{c}\# 2 \\
77^{\circ} \mathrm{F}\end{array}$ & $\begin{array}{c}\# 3, \\
150^{\circ} \mathrm{F}\end{array}$ & $\begin{array}{c}\# 4, \\
210^{\circ} \mathrm{F}\end{array}$ & $\begin{array}{c}\# 5, \\
250^{\circ} \mathrm{F}\end{array}$ \\
\hline \multirow{7}{*}{$\begin{array}{c}0 \text { wt\% } \\
\text { Completely } \\
\text { Spent HCl }\end{array}$} & A & 50 & No & No & No & No & \\
\hline & $B$ & 50 & No & No & No & No & \\
\hline & $C$ & 50 & No & No & No & No & \\
\hline & $D$ & 50 & No & No & No & No & \\
\hline & $E$ & 50 & No & No & No & No & \\
\hline & $\mathrm{F}$ & 50 & No & No & No & No & \\
\hline & No SI & 0 & No & Yes & Yes & Yes & Yes \\
\hline \multirow{13}{*}{$\begin{array}{c}1 \mathrm{wt} \% \\
\text { Partially } \\
\text { Spent HCl }\end{array}$} & \multirow{2}{*}{ A } & 50 & No & No & Yes & Yes & \\
\hline & & 150 & No & Yes & Yes* $^{*}$ & & \\
\hline & \multirow{2}{*}{$B$} & 50 & No & No & Yes & Yes & \\
\hline & & 150 & No & Yes & Yes $^{*}$ & & \\
\hline & \multirow{2}{*}{ C } & 50 & No & No & Yes & Yes & \\
\hline & & 150 & No & No & Yes & Yes & \\
\hline & \multirow{2}{*}{ D } & 50 & No & No & Yes & Yes & \\
\hline & & 150 & No & Yes & Yes $^{*}$ & & \\
\hline & \multirow{2}{*}{$E$} & 50 & No & No & Yes & Yes & \\
\hline & & 150 & No & No & No & No & \\
\hline & \multirow{2}{*}{$F$} & 50 & No & No & Yes & Yes & \\
\hline & & 150 & No & No & Yes & Yes & \\
\hline & No SI & 0 & No & No & Yes & Yes & \\
\hline $\begin{array}{c}5 w t \% \\
\text { Partially } \\
\text { Spent HCl }\end{array}$ & No SI & 0 & No & No & No & No & \\
\hline $\begin{array}{c}10 \mathrm{wt} \% \\
\text { Partially } \\
\text { Spent } \mathrm{HCl}\end{array}$ & No SI & 0 & No & No & No & No & \\
\hline $\begin{array}{c}15 \text { wt } \% \text { Live } \\
\mathrm{HCl}\end{array}$ & No SI & 0 & No & No & No & No & \\
\hline
\end{tabular}

Table 4: Summary of batch tests. 
Citation: He J, Arensman D, Nasr-El-Din HE (2013) Effectiveness of Calcium Sulfate Scale Inhibitors in Spent Hydrochloric Acid/Seawater System. J Pet Environ Biotechnol 4: 159. doi:10.4172/2157-7463.1000159

Page 6 of 6

\section{References}

1. Oddo JE, Smith JP, Tomson MB (1991) Analysis of and Solutions to the CaCO and $\mathrm{CaSO}_{4}$ Scaling Problems Encountered in Wells Offshore Indonesia. SPE Annual Technical Conference and Exhibition, Dallas, Texas, USA.

2. Nasr-El-Din HA, Rosser HR, Hopkins JA (1996) Stimulation of Injection Water Supply Wells in Central Arabia. SPE International Petroleum Exhibition and Conference, Abu Dhabi, United Arab Emirates.

3. He J, Mohamed IM, Nasr-Ei-Din HA (2011) Mixing Hydrochloric Acid and Seawater for Matrix Acidizing: Is it a Good Practice? SPE European Formation Damage Conference, 7-10 June Noodrdwijk, Netherlands.

4. Flint O (1968) Increased Solubility of Calcium Sulphate in Seawater Containing Hydrochloric Acid. Desalination 4: 328-335.

5. Kruchenko VP, Beremzhanov VA (1976) The Solubilities of the Salts in the Calcium Sulphate - Hydrochloric Acid. Water System at $25^{\circ} \mathrm{C}$. Russian Journal of Inorganic Chemistry 21: 152-153.

6. Li Z, Demopoulos GP (2002) $\mathrm{CaSO}_{4}$ Solubilities in Concentrated Aqueous Chloride Solutions. Chloride Metallurgy 2: 561-574

7. Yeboah YD, Samuah SK, Saeed MR (1993) Prediction of Carbonate and Sulfate Scales in Oilfields. Middle East Oil Show, Bahrain.

8. Yeboah YD, Somuah SK, Saeed MR (1993) A New and Reliable Model for Predicting Oilfield Scale Formation. SPE International Symposium on Oilfield Chemistry, New Orleans, Louisiana.

9. Raju KUG, Nasr-El-Din HA (2004) Calcium Sulfate Scale: Field Tests and Model Predictions. NACE Corrosion Conference, New Orleans, USA.

10. Delorey JR, Allen S, McMaster L (1996) Precipitation of Calcium Sulphate During Carbonate Acidizing: Minimizing the Risk. Society of Petroleum Engineers.

11. Tahmasebi HA, Kharrat R (2007) Prediction of Permeability Reduction Rate Due to Calcium Sulfate Scale Formation in Porous Media. SPE Middle East Oil and Gas Show and Conference, Kingdom of Bahrain.

12. Smith CF, Nolan III TJ, Crenshaw PL (1968) Removal and Inhibition of Calcium Sulfate Scale in Waterflood Projects. Journal of Petroleum Technology 20: 1249-1256.

13. Shen J, Crosby CC (1983) Insight into Strontium and Calcium Sulfate Scaling Mechanisms in a Wet Producer. J Petrol Technol 35: 1249-1255.

14. Yuan M, Smith JK, Cooley C, Williamson DA (2004) Effective Mineral Scale Control in Canyon Express, Gulf of Mexico. SPE International Symposium on Oilfield Scale, Aberdeen, United Kingdom.
15. Hoang TA, Ang HM, Rohl AL (2009) Effects of Organic Additives on Calcium Sulfate Scaling in Pipes. Aust J Chem 62: 927-933.

16. Fan C, Kan A, Fu G, Tomson MB, Dong S (2010) Quantitative Evaluation of Calcium Sulfate Precipitation Kinetics in the Presence and Absence of Scale Inhibitors. SPE Journal 15: 977-988.

17. Moore RE, Bischof AE, Robins JD, Brennema DR (1972) One-Step Anhydrite Scale Removal. Materials Protection and Performance 11: 41-41.

18. Jamialahmadi M, Mueller-Steinhagen H (1991) Reduction of Calcium Sulfate Scale Formation during Nucleate Boiling by Addition of EDTA. Heat Transfer Eng 12: 19-26.

19. Al-Khaldi MH, Al-Juhani A, Al-Mutairi SH, Gurmen MN (2011) New Insights into the Removal of Calcium Sulfate Scale. SPE European Formation Damage Conference, Noordwijk, Netherlands.

20. He S, Oddo JE, Tomson MB (1994) The Inhibition of Gypsum and Barite Nucleation in $\mathrm{NaCl}$ Brines at Temperatures from 25 to $90^{\circ} \mathrm{C}$. Appl Geochem 9: 561-567.

21. Tomson MB, Fu G, Watson MA, Kan AT (2003) Mechanisms of Mineral Scale Inhibition. SPE Production \& Operations 18: 192-199.

22. Liu ST, Nancollas GH (1973) The Crystal Growth of Calcium Sulfate Dihydrate in the Presence of Additives. J Colloid Interf Sci 44: 422-429.

23. Amjad Z, Hooley J (1986) Influence of Polyelectrolytes on the Crystal Growth of Calcium Sulfate Dehydrate. J Colloid Interf Sci 111: 496-503.

24. Amjad Z (1988) Calcium Sulfate Dihydrate (Gypsum) Scale Formation on Hea Exchanger Surfaces: The Influence of Scale Inhibitors. J Colloid Interf Sci 123 523-536.

25. Smith PS, Jr. CCC, Rojas AM (2000) Combined Scale Removal and Scale Inhibition Treatments. International Symposium on Oilfield Scale, Aberdeen, United Kingdom.

26. Samy M (2003) Scalemat Restores Production in a Gas Well in GOM, Sugar Land, Texas, Schlumberger Case Study. Sugar Land, Texas: Schlumberger Technology Corporation.

27. Nasr-El-Din HA, Al-Saiari HA, Al-Haiji HH, Samy M, Garcia M, et.al. (2004) A Single-Stage Acid Treatment to Remove and Mitigate Calcium Carbonate Scale in Sandstone and Carbonate Reservoirs. SPE International Symposium on Oilfield Scale, Aberdeen, United Kingdom.

28. Smith PS, Cowie LG, Bourne HM, Grainger M, Heath SM (2001) Field Experiences with a Combined Acid Stimulation and Scale Inhibition Treatment International Symposium on Oilfield Scale, Aberdeen, United Kingdom.

29. Cotruvo JA (2005) Water Desalination Processes and Associated Health and Environmental Issues. Water Conditioning and Purification 47: 13-17. 